\title{
PENGARUH PERPUTARAN AKTIVA TETAP TERHADAP PROFITABILITAS PADA RSUD AL IHSAN BANDUNG PERIODE 2014-2018
}

\author{
Gunardi $^{1}$, Nugraha ${ }^{2}$, Maya Sari $^{3}$ \\ gunardi@upi.edu \\ Prodi Studi Manajemen, Fakultas Ekonomi,Universitas Pendidikan Indonesia
}

\begin{abstract}
Abstrak
Penelitian ini bertujuan untuk mengetahui pengaruh perputaran aktiva tetap terhadap profitabilitas Pada RSUD Al Ihsan Bandung Periode 2014-2018. Metode penelitian yang digunakan yaitu metode kualitatif dan teknik Analisis data yaitu koefisien korelasi Pearson dan koefisien Determinasi. Hasil penelitian pengaruh perputaran aktiva tetap terhadap profitabilitas Pada RSUD Al Ihsan Bandung Periode 2014-2018 sebesar 88,5\% dengan kata lain dapat dikatakan bahwa pengaruh Perputaran aktiva tetap terhadap Profitabilitas di RSUD Al Ihsan Bandung dinyatakan Kuat, dan sisanya sebesar 11,5,\% dipengaruhi oleh faktor lain yang tidak diteliti oleh penulis seperti Penjualan, Laba dll. Hambatan yang muncul yaitu 1) Pendapatan RSUD Al Ihsan menjadi tidak maksimal karena pemanfaatan aktiva tetap yang kurang maksimal sehinga presentasi Profitabilitas menjadi menurun. 2) Penyusutan Aktiva tetap secara cepat mengakibatkan menurunnya kualitas dari RSUD Al Ihsan dikarenakan kurangnya perawatan secara berkala oleh pihak rumah sakit. Saran yang diberikan adalah dengan cara 1) Diharapkan rumah sakit dapat memanfaatkan setiap asset yang dimilikinya dengan lebih efektif sehingga laba atau profit yang dicapai dapat lebih meningkat. 2) Sebaiknya mempercepat persediaan melalui proses penjualan agar memperoleh hasil yang dapat dengan cepat diubah menjadi kas juga.
\end{abstract}

\section{Kata Kunci : Perputaran Aktiva Tetap; Profitabilitas}

\begin{abstract}
This study aims to determine the influence of fixed asset rotation on profitability at Al Ihsan Hospital Bandung Period 2014-2018. The research method used is a qualitative method and data analysis techniques namely Pearson correlation coefficient and determination coefficient. The results of the study of the effect of fixed asset rotation on profitability In Al Ihsan Hospital Bandung 2014-2018 period amounted to $88.5 \%$ in other words it can be said that the effect of fixed asset turnover on profitability in Al Ihsan General Hospital Bandung was declared strong, and the remaining 11.5,\% influenced by other factors not examined by authors such as Sales, Profits etc. Obstacles that arise are 1) Revenue from Al Ihsan General Hospital is not optimal because the utilization of fixed assets is not optimal so that the presentation of Profitability decreases. 2) Depreciation of fixed assets quickly results in a decrease in the quality of Al Ihsan General Hospital due to the lack of regular maintenance by the hospital. The advice given is by way of 1) It is expected that hospitals can use each asset they have more effectively so that profits or profits can be increased. 2) It is better to speed up inventory through the sales process in order to obtain results that can be quickly converted into cash as well.
\end{abstract}

\section{Keywords: Fixed Asset Rotation, Profitability}


Indonesian Journal Of Strategic Management

Vol 3, Issue 1, February 2020

DOI: https://doi.org/10.25134/ijsm.v3i1.2815
Printed ISSN 2614-5391, e-ISSN 2614-2406

https://journal.uniku.ac.id/index.php/ijsm

\section{PENDAHULUAN}

Perusahaan merupakan salah satu unit kegiatan produksi yang mengelola sumber-sumber ekonomi untuk menyediakan barang dan jasa bagi masyarakat dengan tujuan untuk memperoleh keuntungan atau profitabilitas dan dapat memuaskan kebutuhan masyarakat. Perusahaan bertugas mengelola sumber ekonomi itulah perusahaan mendapatkan keuntungan. Dalam dunia bisnis persaingan menjadi suatu hal yang biasa dan ini menjadi suatu tantangan tersendiri bagi perusahaan yang siap terjun dalam dunia persaingan ketat.

Untuk bertahan dalam per-saingan yang ketat ini, pihak manajemen perusahaan harus meng-optimalkan kegiatan usaha perusaha-an tujuan suatu perusahaan ditinjau dari sudut pandang ekonomi adalah memperoleh keuntungan (profitabilitas), menjaga kelangsung-an hidup dan kesinambungan operasi perusahaan.

Profitabilitas adalah kemampuan perusahaan untuk menghasilkan laba selama periode tertentu. Profit merupakan tujuan yang paling mendasar dari operasi perusahaan. Ada banyak ukuran profitabilitas tapi dalam hal ini penulis menggunakan ROA, Alat yang umum digunakan untuk mengevaluasi profitabilitas.

Profitabilitas menunjukkan suatu perbandingan antar laba dan aktiva yang digunakan. Laba bersih erat kaitannya dengan dengan pendapatan usaha, dimana ketika usaha meningkat maka pendapatan juga meningkat. Setiap perusahaan mempunyai harta (aktiva) untuk mendukung kegiatan usahanya. Aktiva tetap berwujud besifat relatif permanen menunjukkan sifat dari aktiva tetap yang dapat dipergunakan dalam jangka waktu yang cukup lama. Contoh dari aktiva tetap antara lain bangunan, mesin, peralatan, kendaraan dan sebagainya. Pada umumnya aktiva tetap merupakan harta perusahaan yang nilainya materil dibandingkan bentuk harta lainnya. Aktiva tetap juga disusutkan dengan menggunakan harga perolehan aktiva tersebut kemudian dibebankan kepada periode.

Untuk menghadapi persaingan bisnis yang kompetitif maka, diperlukan suatu penanganan dan pengelolaan sumber daya yang dilakukan oleh pihak manajemen dengan baik. Hal ini dilakukan untuk menghadapi tantangan persainganyang semakin tinggi sehingga menuntut peningkatan efisiensi dan efektifitas organisasi. Untuk mencapai tingkat efisiensi dan efektifitas yang diharapkan perlu perubahan perubahan organisasi diseluruh aspek baik mutu pelayanan maupun aspek keuangan. Hal ini juga berlaku untuk organisasi atau perusahaan yang bergerak dibidang jasa seperti rumah sakit. Rumah sakit merupakan bentuk sarana pelayanan kesehatan dan merupakan institusi yang 
Indonesian Journal Of Strategic Management

Vol 3, Issue 1, February 2020

DOI: https://doi.org/10.25134/ijsm.v3i1.2815
Printed ISSN 2614-5391, e-ISSN 2614-2406

https://journal.uniku.ac.id/index.php/ijsm sarat dengan mengemban fungsi sosial kepada masyarakat dengan selalu mengutamakan kemanusiaan, serta kepuasan masyarakat terhadap pelayanan kesehatan yang diberikan, maka dari itu manajemen rumah sakit harus terus meningkatkan kinerjanya.

Setiap rumah sakit mempunyai harta (aktiva) untuk mendukung kegiatannya. Aktiva tetap berwujud besifat relatif permanen menunjukkan sifat dari aktiva tetap yang dapat dipergunakan dalam jangka waktu yang cukup lama. Aktiva memiliki tiga karakteristik utama yaitu, memiliki manfaat ekonomi dimasa mendatang, dikuasai oleh suatu unit usaha, hasil dari transaksi masa lalu. Aktiva tetapl azimnya dicatat sebesar harga perolehannya. Pada umumnya aktiva tetap merupakan harta yang nilainya materil dibandingkan bentuk harta lainnya. Aktiva tetap juga disusutkan dengan menggunakan harga perolehan aktiva tersebut kemudian dibebankan kepada periode-periode masa penggunaanya. Investasi yang tertanam dalam aktiva tetap cukup besar nilainya, sehingga mutlak diperlakukan pengelolaan yang baik. Pengawasan terhadap aktiva tetap didasarkan kepada perencanaan yang diatur dalam bentuk anggaran mengenai pengadaan, perbaikan ataupun penghapusan aktivatetap.

Dana yang ditanamkan dalam aktiva tetap mengalami proses perputaran. Rumah sakit mengadakan investasi dalam aktiva tetap dengan harapan akan memperoleh lagi dana yang diinvestasikan pada aktiva tetap tersebut. Dana yang tertanam di dalamnya akan diterima kembali oleh perusahaan dalam waktu beberapa tahun secara berangsurangsur melalui depresiasi menurut Bambang Riyanto, (2001:115). Aktiva tetap yang penting untuk diperhatikan adalah bangunan dan fasilitas yang tersedia pada rumah sakit (Gedung, peralatan medis, peralatan kantor, dan yang lainnya). Agar dapat memberikan pelayanan yang maksimal, rumahsakit perlu memperhatikan kondisi gedung dan fasilitas yang tersedia demi kenyamanan pasien dan efektifitas kinerja pelayanan. Maka dari itu, perlu adanya pembaharuan dan perawatan fasilitas rumah sakit agar setiap pasien yang melakukan pengobatan dapat dilayani dengan baik.

Rumah Sakit Umum Daerah Al Ihsan merupakan salah satu Rumah Sakit Umum DaerahYang berada di Jl. Ki Astramanggala - Baleendah Kabupaten Bandung. RSUD Al Ihsan berdiri pada tanggal 28 Desember 1998, pada awalnya rumah sakit ini merupakan rumah sakit swasta yang bernama RSI Al Ihsan. Kemudian berdasarkan hasil pertemuan antara pihak pengelola RSI Al Ihsan dengan Asisten Daerah (Asda) Provinsi Jabar Bidang Administrasi, memutuskan pengelolaan rumah sakit berpindah ke Pemerintah Provinsi Jawa Barat. 
Indonesian Journal Of Strategic Management

Vol 3, Issue 1, February 2020

DOI: https://doi.org/10.25134/ijsm.v3i1.2815
Printed ISSN 2614-5391, e-ISSN 2614-2406

https://journal.uniku.ac.id/index.php/ijsm
Dengan memiliki fasilitas gedung dan peralatan medis memadai, pasien yang berkunjung akan dapat ditangani lebih efektif. Jika menetapkan kebijakan aktiva tetap yang tepat, maka profit yang dihasilkan dari investasi yang telah dikeluarkan akan lebih maksimal dan investasi yang dilakukan pun efektif dan efisien. Untuk mengetahui apakah manajemen telah melakukan investasi dengan tepat, perlu dilakukan analisis laporan keuangan. Tujuan melakukan analisis laporan keuangan perusahaan untuk mengetahui keadaan serta perkembangan financial dengan hasil yang telah dicapai diwaktu yang lampau dan diwaktu yang sedang berjalan. Serta memahami kondisi keuangan dan apa yang dihasilkannya. Menurut Sofyan S Harahap (2008:304), "Salah satu kinerja yang diukur melalui laporan keuangan adalah profitabilitas. Profitabilitas merupakan kemampuan perusahaan mendapatkan laba melalui semua kemampuan dan sumber yang ada seperti kegiatan penjualan, kas, modal, jumlah karyawan, jumlah cabang, dan sebagainya".

Profitabilitas dapat dijadikan suatu gambaran bagaimana kemampuan rumah sakit dalam menghasilkan keuntungan, atas harta yang dimilikinya. Nilai profitabilitas tinggi tentu menggambarkan semakin baik. Sebaliknya, nilai profitabilitas yang rendah mengindikasikan manajemen belum efektif dan efisien dalam mengelola aktiva untuk menghasilkan keuntungan. Tingkat profitabilitas yang menunjukan kaitannya dengan investasi, yaitu dengan menggunakan Return On Assets (ROA). Return On Assets (ROA) akan mengidentifikasikan kelemahan serta kekuatan keuangan perusahaan dan dapat menjelaskan perbandingan data keuangan perusahaan untuk meneliti arah pergerakannya. Aset merupakan salah satu sumber yang dapat menaikan ROA. Melihat kondisi tersebut dimana, aktiva tetap selalu bertambah seharusnya dapat meningkatkan pendapatan rumah sakit.

Menurut Sofyan Syafri Harahap (2008:304) bahwa, "Semakin cepat aktiva berputar maka semakin cepat memperoleh laba". Teori yang dikemukakan menjelaskan semakin tinggi perputaran aktiva menunjukan semakin cepat pula laba yang didapatkan.

Berdasarkan latar belakang diatas maka dalam pembuatan laporan tugas akhir ini penulis tertarik untuk melakukan penelitian dan mengembangkannya dalam bentuk karya tulis ilmiah dengan judul "PENGARUH PERPUTARAN AKTIVA TETAP TERHADAP PROFITABILITAS PADA RSUD AL IHSAN BANDUNG PERIODE 20142018".

\section{Pokok Permasalahan}

Adapun pokok permasalahan dalam penulisan tugas akhir inidan dari hasil 
Indonesian Journal Of Strategic Management

Vol 3, Issue 1, February 2020

DOI: https://doi.org/10.25134/ijsm.v3i1.2815
Printed ISSN 2614-5391, e-ISSN 2614-2406 https://journal.uniku.ac.id/index.php/ijsm penelitian langsung maka dapat dikemukakan pokok permasalahan dalam pembahasan tugas akhir ini adalah Pengaruh Perputaran Aktiva Tetap Terhadap Profitabilitas Pada RSUD Al Ihsan Bandung Periode 2014-2018.

\section{Pertanyaan Penelitian}

a. Berapa kali perputaran aktiva tetap Pada RSUD Al Ihsan Bandung Periode 2014-2018?

b. Seberapa besar profitabilitas Pada RSUD Al Ihsan Bandung Periode 2014-2018?

c. Seberapa besar pengaruh perputaran aktiva tetap terhadap profitabilitas Pada RSUD Al Ihsan Bandung Periode 2014-2018?

d. Permasalahan apa saja yang berkaitan dengan perputaran aktiva tetap terhadap profitabilitas Pada RSUD Al Ihsan Bandung Periode 2014-2018?

e. Bagaimana upaya penyelesaian masalah yang berkaitan dengan perputaran aktiva tetap terhadap profitabilitas Pada RSUD Al Ihsan Bandung Periode 2014-2018?

\section{Tujuan Penelitian}

Adapun tujuan dari pembuatan laporan tugas Untuk mengetahui berapa kali perputaran aktiva tetap Pada RSUD Al Ihsan Bandung Periode 2014-2018.

a. Untuk mengetahui berapa kali perputaran aktiva tetap Pada RSUD Al Ihsan Bandung Periode 2014-2018 b. Untuk mengetahui seberapa besar protabilitas pada RSUD Al Ihsan Bandung Periode 2014-2018.

c. Untuk mengetahui seberapa besar pengaruh perputaran aktiva tetap terhadap protabilitas pada RSUD Al Ihsan Bandung Periode 2014-2018.

d. Untuk mengetahui permasalahan apa saja yang berkaitan dengan perputaran aktiva tetap terhadap profitabilitas Pada RSUD Al Ihsan Bandung Periode 2014-2018.

e. Untuk mengetahui Bagaimana upaya penyelesaian masalah yang berkaitan dengan perputaran aktiva tetap terhadap profitabilitas Pada RSUD Al Ihsan Bandung Periode 2014-2018.

\section{Manfaat Laporan}

\section{A. Bagi Penulis}

1) Untuk menambah pengetahuan tentang RSUD Al Ihsan.

2) Untuk menyelesaikan sebagian persyaratan Program Diploma III Administrasi Keuangan di Politeknik Piksi Ganesha

3) Untuk menambah wawasan penulis mengenai kegiatan-kegiatan operasiona IRSUD Al Ihsan.

\section{B. Bagi RSUD Al Ihsan}

1) Menambah literature atau referensi, serta informasi di RSUD Al Ihsan.

2) Saran penulis dapat dijadikan sebagai masukan untuk pada RSUD Al Ihsan. 
Indonesian Journal Of Strategic Management

Vol 3, Issue 1, February 2020

DOI: https://doi.org/10.25134/ijsm.v3i1.2815
Printed ISSN 2614-5391, e-ISSN 2614-2406

https://journal.uniku.ac.id/index.php/ijsm

\section{Bagi Politeknik Piksi Ganesha}

1) Dapat dijadikan sebagai pengetahuan.

2) Menambah literature atau referensi, serta informasi di perpustakaan kampus.

\section{Pengertian Manajemen Keuangan}

Menurut Bambang Riyanto (2013:4), adalah: "Manajemen Keuangan adalah keseluruhan aktivitas yang bersangkutan dengan usaha untuk mendapatkan dana dan menggunakan atau mengalokasian dana tersebut".

Sedangkan menurut Horne \& Wachowicz (2012:2) yang diterjemahkan oleh Mubarakah, manajemen keuangan adalah : "Manajemen keuangan berkaitan dengan perolehan aset, pendanaan dan manajemen aset dengan didasari beberapa tujuan umum".

\section{Tujuan Manajemen Keuangan}

Tujuan manajemen keuangan menurut Susan Irawati (2006:4) adalah untuk memaksimalkan profit atau keuntungan dan meminimalkan biaya(expensataucost) guna mendapatkan suatu pengembalian keputusan yang maksimum, dalam menjalankan perusaha-an ke arah perkembangan dan perusahaan yang berjalanatau survive dan expantion.

\section{Fungsi Manajemen Keuangan}

Menurut James C, Van Horne \& John M, Wachowicz, JR (2012:3), menyatakan bahwa fungsi manajemen keuangan terdiri dari tiga keputusan utama yang harus dilakukan oleh suatu perusahaanyaitu:

1) Keputusan investasi adalah hal yang paling penting dari ketiga keputusan ketika perusahaan ingin menciptakan nilai. Dan bagaimana manajer keuangan harus mengalokasikan dana ke dalam bentuk-bentuk investasi yang akan dapat mendatangkan keuntungan di masa yangakan datang. Bentuk, macam, dan komposisi dariinvestasi.

2) Keputusan pendanaan adalah menyangkut beberapa hal. Pertama, keputusan mengenai penetapan sumber dana yang diperlukan untuk membiayai investasi. Sumber dana yang akan digunakan untuk membiayai investasi tersebut dapat berupa hutang jangka pendek, hutan.

\section{Konsep Laporan Keuangan}

Menurut Harahap (2013:105) laporan keuangan menggambarkan kondisi keuangan dan hasil usaha suatu perusahaan pada saat tertentu atau jangka waktu tertentu. Laporan keuangan menjadi sarana informasi bagi pengembalian keputusan. Tujuan laporan keuangan menurut Bernstein (1983) dalam Harahap (2013) adalah :

1) Screening

Mengetahuisituasidankondisiperusa haandarilaporankeuangantanpapergi langsung kelapangan. 


\section{2) Understanding}

Memahami perusahaan, kondisi keuangan, dan hasil usahanya.

3) Forcasting

Meramalkan kondisi keuangan di masa yang akan datang.

4) Diagnosis

Melihat kemungkinan adanya masalah-masalah yang terjadi dalam manajemen, operasi, keuangan, atau masalah lain dalamperusahaan.

5) Evaluation

Menilai prestasi manajemen dalam mengelola perusahaan.

Laporan keuangan dapat menggambarkan posisi keuangan perusahaan, hasil usaha perusahaan dalam satu periode dan arus dana (kas) perusahaan dalam periode tertentu. Jika informasi di suatu laporan keuangan disajikan dengan benar, maka informasi tersebut sangat berguna untuk siapa saja yang akan mengambil keputusan.

\section{Fungsi Laporan Keuangan}

Laporan keuangan yang disusun dan disajikan pada dasarnya digunakan untuk mengkomunikasikan informasi keuangan dan dari suatu perusahaan kepada mereka yang berkepentingan bagi perusahaan tersebut. Fungsi laporan keuangan menurut Harahap (2013:7) adalah sebagai berikut :

1) Pemilikperusahaan

a. Menilai prestasi atau hasil yang diperolehmanajemen; b. Mengetahui hasil dividen yang akanditerima;

c. Menilai posisi keuangan danpertumbuhannya;

d. Mengetahui nilai saham dan laba perlembarsaham;

e. Memperediksi kondisi perusahaan di masadatang;

f. Mempertimbangkan menambah atau mengurangiinvestasi.

2) Manajemenperusahaan

a. Alatuntuk memper-tanggung jawabkan pengelola-an kepada pemilik;

b. Mengukur tingkat biaya dari setiap kegiatan operasi perusahaan, divisi, bagian, atau segmen;

Mengukur tingkat efisiensi dan

c. tingkat keuntungan perusaha-an, divisi, bagian, atausegmen;

d. Menilai hasil kerja individu yang diberi tugas dan tanggungjawab;

e. Menjadi bahan pertimbangan dalam menentukan perlu tidaknya kebijaksanaan baru;

f. Memenuhi ketentuan dalam UU, peraturan, AD (Anggaran Dasar), Pasar Modal, dan lembaga regulator lainnya.

3) Investor

a. Menilai kondisi keuangan dan hasil usaha perusahaan;

b. Menilai kemungkinan menanamkan dana dalam perusahaan;

c. Menilai kemungkinan divestasi 
Indonesian Journal Of Strategic Management

Vol 3, Issue 1, February 2020

DOI: https://doi.org/10.25134/ijsm.v3i1.2815

(menarik

investasi)

dariperusahaan;

d. Menjadi dasar prediksi kondisi perusahaan di masadatang.

4) Kreditur atau Banker

a. Menilai kondisi keuangan dan hasilperusahaan;

b. Menilai kualitas jaminan kredit/investasi untuk menopang kredit yang akandiberikan;

c. Melihat dan memprediksi prospek keuntungan yang mungkin diperoleh dari perusahaan atau menilai rate of return perusahaan;

d. Menilai kemampuan likuiditas, solvabilitas, rentabilitas, perusahaan sebagai dasar dalam pertimbangan keputusan kredit;

e. Menilai sejauh mana perusahaan mengikuti perjanjian kredit yang sudahdisepakati.

5) Pemerintah dan Regulator

a. Menghitung dan menetapkan jumlah pajak yang harus dibayar;

b. Sebagai dasar penetapan-penetapan kebijaksanaan baru;

c. Menilai apakah perusahaan memerlukan bantuan atau tindakanlain;

d. Menilai perusahaan terhadap aturan yangditetapkan;

e. Bagi lembaga pemerintah lainnya bisa menjadi bahan penyusun data danstatistik.

6) Analis, Akademis, Pusat DataBisnis
Printed ISSN 2614-5391, e-ISSN 2614-2406 https://journal.uniku.ac.id/index.php/ijsm

Laporan keuangan ini penting sebagai bahan atau sumber informasi primer yang akan diolah sehingga menghasilkan informasi yang bermanfaat bagi analisis, ilmu pengetahuan, dan komoditi informasi.

\section{Konsep Aktiva}

Pengertian aktiva menurut Kasmir (2010:76) adalah: "Aktiva, merupakan harta atau kekayaan (aset) yang dimiliki oleh perusahaan, baik pada saat tertentu".

Sedangkan menurut Rudianto (2012:28), pengertian aktiva yaitu:Aset adalah sumber daya yang dimiliki perusahaan. Asset merupakan kumpulan dari berbagai kekayaan yang dimiliki perusahaan yang akan digunakan untuk memperoleh penghasilan selama tahun berjalan maupun tahun-tahun berikutnya.

Aktiva lancar merupakan harta atau kekayaan yang segera dapat diuangkan (ditunaikan) pada saat dibutuhkan dan paling lama satu tahun.

Aktiva tetap adalah aktiva berwujud yang mempunyai umur relatif permanen memberikan manfaat kepada perusahaan selama bertahun-tahun yang dimiliki dan digunakan untuk operasi sehari-hari dalam rangka kegiatan normal dan tidak dimaksudkan untuk dijual kembali (bukan barang dagangan) serta nilainya relatif material. 
Indonesian Journal Of Strategic Management

Vol 3, Issue 1, February 2020

DOI: https://doi.org/10.25134/ijsm.v3i1.2815

\section{Perputaran Aktiva Tetap}

Perputaran aktiva tetap merupakan salah satu unsur dalam menentukan tinggi rendahnya tingkat profitabilitas perusahaan. Perusahaan melakukan investasi dalam aktiva tetap dengan harapan dapat memperoleh kembali dana yang di tanamkan dalam aktiva tersebut. Perputaran aktiva tetap akan diterima kembali keseluruhannya oleh perusahaan dalam waktu beberapa tahun dan kembali secara berangsur-angsur melalui depresiasi. Jumlah dana yang terikat dalam aktiva tetap akan berangsur-angsur berkurang sesuai dengan metode penyusutan yang digunakan oleh perusahaan. Perputaran aktiva tetap dapat menentukan tingkat profitabilitasperusahaan.

\section{METODE}

\section{Teknik Pengumpulan Data}

Metode penelitian yang di-gunakan oleh Teknik pengumpulan data yang digunakan penulis pada penelitian kali ini adalah dengan cara:

1) Penelitian Lapangan

a. Wawancara

Penulis menggunakan teknik pengumpulan data melalui wawancara kepada pihak-pihak yang bersangkutan dengan topik yang diangkat pada penelitian ini. Dengan wawancara, seseorang dapat mengungkapkan kenyataan yang terjadi sesuai dengan apa yang sedang dipikirkan. Melalui tanya
Printed ISSN 2614-5391, e-ISSN 2614-2406 https://journal.uniku.ac.id/index.php/ijsm

jawab, kita dapat memasuki alam pikiran orang lain sehingga kita memperoleh informasi yang sedang kita perlukan. Dari cara tersebut, penulis dapat memperoleh informasi yang objektif tentang masalah yang dihadapi.

b. Observasi

Penulis juga melakukan observasi terhadap kegiatan operasional perusahaan. Penulis melakukan observasi tidak langsung sehingga penulis tidak terlibat langsung dalam kegiatan operasional perusahaan dan hanya sebagai pengamat independen.

2) Penelitian Kepustakaan

Penulis juga melakukan teknik pengumpulan data melalui penelitian kepustakaan. Penulis mengumpulkan data dan informasi dari berbagai buku yang menjadi sumber penulis untuk memperoleh informasi.

\section{HASIL DAN PEMBAHASAN}

\section{A. Analisis Regresi Linear Sederhana}

Teknik analisis data yang akan digunakan peneliti adalah regresi linier sederhana karena didasarkan pada hubungan fungsional ataupun kausal satu variabel independen dengan satu variabel dependen. Persamaan umum regresi linier sederhana pada Sugiyono (2016 : 237238)dapat dihitung menggunakan IBM SPSS 20, sebagai berikut: 
Indonesian Journal Of Strategic Management

Vol 3, Issue 1, February 2020

DOI: https://doi.org/10.25134/ijsm.v3i1.2815
Printed ISSN 2614-5391, e-ISSN 2614-2406

https://journal.uniku.ac.id/index.php/ijsm

\section{Hasil Analisis Regresi Linear Sederhana}

Sumber : Hasil Penelitian Penulis 2019

$Y=-2.416 .433 .184,063+0,993$

Dari hasil perhitungan diatas, maka dapat disimpulkan bahwa berdasarkan hasil perhitungan analisis regresi linier sederhana dapat diketahui koefisien dari Variabel Perputaran aktiva tetapsebesar 2.416.433.184,063, yang berarti bahwa apabila nilai seluruh variabel bebas (X) sama dengan nol, maka Profitabilitas akan bernilai 0,993 . Jika nilai konstanta pada Perputaran aktiva tetap sebesar 1, maka pada Profitabilitas akan bernilai sebesar 2.416.433.185,056. Maka diambil kesimpulan semakin besar variabel Perputaran aktiva tetap makan semakin besar pula Profitabilitas di RSUD Al Ihsan Bandung

\section{B. Analisis Korelasi Pearson}

Uji korelasi Pearson digunakan untuk mencari keeratan hubungan antara variabel dependen dengan variabel independen. Karena skala yang digunakan dalam analisis ini berbentuk interval, maka digunakan rumus untuk mencari keeratan hubungan antara variabel dependen dengan variabel independen. Berikut hasil dari uji Kolerasi dengan menggunakan IBM SPSS 20:

\section{Hasil Korelasi Pearson Variabel X dan Variabel Y}

Sumber : Hasil Penelitian Penulis 2019
Variabel dependen dan variabel independen (Perputaran aktiva tetap) memiliki nilai koefisien 0,941 , maka dari hasil tersebut dapat disimpulkan bahwa derajat tingkat hubungan antara Perputaran aktiva tetap dengan Profitabilitas di RSUD Al Ihsan Bandung dinyatakan Sangat kuat yang berarti semakin besar hubungan variabel Perputaran aktiva tetap maka, semakin besar pula Profitabilitas terjadi.

\section{Analisis Koefisien Determinasi}

Untuk mengetahui seberapa besar pengaruh Perputaran aktiva tetap terhadap Profitabilitas karyawan di RSUD Al Ihsan Bandung dapat dihitung menggunakan IBM SPSS 20, sebagai berikut:

\section{Hasil Koefisien Determinasi}

Sumber : Hasil Penelitian Penulis 2019

Dari hasil Tabel 3.5 dapat diketahui bahwa pengaruh Perputaran aktiva tetap terhadap Profitabilitas di RSUD Al Ihsan Bandung sebesar 88,5\% dengan kata lain dapat dikatakan bahwa pengaruh Perputaran aktiva tetap terhadap Profitabilitas di RSUD Al Ihsan Bandung dinyatakan Kuat, dan sisanya sebesar $11,5, \%$ dipengaruhi oleh faktor lain yang tidak diteliti oleh penulis seperti Penjualan, Laba dll. 
Indonesian Journal Of Strategic Management

Vol 3, Issue 1, February 2020

DOI: https://doi.org/10.25134/ijsm.v3i1.2815

\section{Uji Hipotesis (Uji t)}

Uji t dilakukan untuk mengetahui apakah masing-masing variabel bebas mempunyai pengaruh yang signifikan terhadap variabel terikat. Selanjutnya dalam uji ini untuk mendapatkan nilai

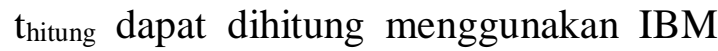
SPSS 20, sebagai berikut:

\section{Hasil Uji Hipotesis (Uji t)}

Sumber : Hasil Penelitian Penulis 2019

Dari perhitungan diatas maka dapat ditarik kesimpulan bahwa $t_{\text {hitung }}<t_{\text {tabel }}$ dengan nilai sebesar $(4,809>0,924)$, maka $\mathrm{H}_{0}$ akan ditolak dan $\mathrm{H}_{1}$ akan diterima, artinya masing-masing variabel bebas mempengaruhi secara signifikan terhadap variabel terikat.

3.8 Permasalahan apa saja yang berkaitan dengan perputaran aktiva tetap terhadap profitabilitas Pada RSUD Al Ihsan Bandung Periode 2014-2018

a. Pendapatan RSUD Al Ihsan menjadi tidak maksimal karena pemanfaatan aktiva tetap yang kurang maksimal sehinga presentasi Profitabilitas menjadi menurun.

b. Penyusutan Aktiva tetap secara cepat mengakibatkan menurunnya kualitas dari RSUD Al Ihsan dikarenakan kurangnya perawatan secara berkala oleh pihak rumah sakit.
Printed ISSN 2614-5391, e-ISSN 2614-2406 https://journal.uniku.ac.id/index.php/ijsm

3.9 Upaya penyelesaian masalah yang berkaitan dengan perputaran aktiva tetap terhadap profitabilitas Pada RSUD Al Ihsan Bandung Periode 2014-2018.

a. Meningkatkan operasional dan pemasaran, baik pada bisnis inti yaitu Perawatan,obat, dan jasa operasi dengan memaksilmalkan aktiva tetap yang ada sehingga memacu peningkatan profit pada RSUD Al Ihsan.

b. Melakukan Pelatihan kepada karyawan RSUD Al Ihsan Agar lebih memperhatikan kondisi Aktiva tetap yang ada sehingga penggunaan aktiva tetap dapat secara maksimal diberikan kepada pasien.

c. Meningkatkan kualitas pada pelayanan serta Quality Control terhadap pasien dan produk yang dijual, Maka akan meningkatkan dan mempertahankan pendapatan dari Pasien pada RSUD Al ihsan.

\section{PENUTUP}

\section{Kesimpulan}

Berdasarkan hasil Penelitian dan pembahasan mengenai pengaruh perputaran aktiva tetap terhadap profitabilitas Pada RSUD Al Ihsan Bandung Periode 2014-2018 yang telah diuraikan pada bab sebelumnya, maka penulis mengambil kesimpulan bahwa :

a. Berdasarkan hasil pegelolaan data tentang variabel perputaran aktiva 
Indonesian Journal Of Strategic Management

Vol 3, Issue 1, February 2020

DOI: https://doi.org/10.25134/ijsm.v3i1.2815

tetap selama 5 tahun terakhir yaitu tahun 2014-2018 terus mengalami naik dan turun. Perputaran aktiva tetap pada RSUD Al Ihsan Bandung ini masih mengalami fluktuatif dan mencapai rata-rata $(1,23+2,13+1,83+2,15+1,95 / \quad 5=$ $1,86)$ kali dalam kurun waktu 20142018. Dalam hal ini penggunaan aktiva sudah Baik dimana aktiva tetap yang digunakan untuk menunjang operasi perusahaan dapat menghasilkanpenjualan yang terus meningkat tiap tahunnya.

b. Berdasarkan hasil pengelolaan data tentang profitabilitas pada RSUD Al Ihsan Bandung cenderung meningkat selama periode 2014-2018 meskipun terkadang naik dan turun. Perkembangan ROA pada RSUD Al Ihsan Bandung dalam kurun waktu 5 tahun dapat dikatakan baik karena rasio profitabilitas yang didapat perusahaan cenderung naik dalam kurun waktu tersebut. berdasarkan analisis penulis dan penelitian di atas, bahwa profitabilitas (ROA) pada RSUD Al Ihsan Bandung tidak stabil, ini dikarenakan laba perusahaan mengalami kenaikan dan penurunan yang disebabkan karena adanya persaingan dan semakin banyak Rumah sakit dikota Bandung.

c. Berdasarkan hasil pengelolaan data untuk mengetahui seberapa besar pengaruh Perputaran aktiva tetap
Printed ISSN 2614-5391, e-ISSN 2614-2406 https://journal.uniku.ac.id/index.php/ijsm

terhadap Profitabilitas di RSUD Al Ihsan Bandung sebesar 88,5\% dengan kata lain dapat dikatakan bahwa pengaruh Perputaran aktiva tetap terhadap Profitabilitas di RSUD Al Ihsan Bandung dinyatakan Kuat, dan sisanya sebesar $11,5, \%$ dipengaruhi oleh faktor lain yang tidak diteliti oleh penulis seperti Penjualan, Laba dll.

d. Permasalahan apa saja yang berkaitan dengan perputaran aktiva tetap terhadap profitabilitas Pada RSUD Al Ihsan Bandung Periode 2014-2018 yaitu:

1) Pendapatan RSUD Al Ihsan menjadi tidak maksimal karena pemanfaatan aktiva tetap yang kurang maksimal sehinga presentasi Profitabilitas menjadi menurun.

2) Penyusutan Aktiva tetap secara cepat mengakibatkan menurunnya kualitas dari RSUD Al Ihsan dikarenakan kurangnya perawatan secara berkala oleh pihak rumah sakit.

e. Permasalahan apa saja yang berkaitan dengan perputaran aktiva tetap terhadap profitabilitas Pada RSUD Al Ihsan Bandung Periode 2014-2018 yaitu:

1) Meningkatkan operasional dan pemasaran, baik pada bisnis inti yaitu Perawatan,obat, dan jasa operasi dengan memaksilmalkan aktiva tetap yang ada sehingga 
Indonesian Journal Of Strategic Management

Vol 3, Issue 1, February 2020

DOI: https://doi.org/10.25134/ijsm.v3i1.2815

memacu peningkatan profit pada RSUD Al Ihsan.

2) Melakukan Pelatihan kepada karyawan RSUD Al Ihsan Agar lebih memperhatikan kondisi Aktiva tetap yang ada sehingga penggunaan aktiva tetap dapat secara maksimal diberikan kepada pasien.

3) Meningkatkan kualitas pada pelayanan serta Quality Control terhadap pasien dan produk yang dijual, Maka akan meningkatkan dan mempertahankan pendapat-an dari Pasien pada RSUD Al -Ihsan..

\section{Saran}

Berdasarkan kesimpulan di atas, peneliti berupaya untuk memberikan saran atau masukan mengenai perputaran aktiva tetap dan profitabilitas Pada RSUD Al Ihsan Bandung Periode 2014-2018 sebagai berikut :

a. Diharapkan rumah sakit dapat memanfaatkan setiap asset yang dimilikinya dengan lebih efektif sehingga laba atau profit yang dicapai dapat lebih meningkat. Rumah sakit tidak menjadikan aktiva tetep sebagai sumber investasi untuk meningkatkan laba atau profit, karena aktiva tetap hanya memberikan sedikit pengaruh terhadap profitabilitas.

b. Selain aktiva tetap, perputaran persediaan pada penelitian ini
Printed ISSN 2614-5391, e-ISSN 2614-2406 https://journal.uniku.ac.id/index.php/ijsm

sebaiknya mempercepat persediaan melalui proses penjualan agar memperoleh hasil yang dapat dengan cepat diubah menjadi kas juga.

c. Bagi peneliti selanjutnya yang akan melakukan penelitian lebih dalam mengenai permasalahan ini disarankan agar periode penelitian lebih lama, misalnya 10 tahun. Karena dalam penelitian ini peneliti hanya mengambil jangka waktu penelitian lima tahun dari tahu 2009-2018. Dengan jangka waktu penelitian yang lebih lama, akan memberikan hasil penelitian yang lebih maksimal.

\section{DAFTAR PUSTAKA}

Agus, R. Sartono. (2010). Manajemen Keuangan Teori dan Aplikasi.Edisi Keempat. BPFE. Yogyakarta.

Harjito, Agus. dan Martono. (2010). Manajemen Keuangan. Ekonisia. Yogyakarta.

Hanafi, Mamduh M. dan Abdul Halim. (2014). Analisis Laporan Keuangan, Edisi tujuh. UPP AMP YKPN, Yogyakarta.

Harahap, Sofyan Syarif. (2013). Analisa Kritis Atas Laporan Keuangan. PT Raja Grafindo Persada. Jakarta.

Horne, James C. Van., dan John M Wachowicz, Jr. (2012). Prinsipprinsip Manajemen Keuangan (Edisi 13). Salemba Empat. Jakarta.

Irawati, Susan. (2006). Manajemen Keuangan. Pustaka. Bandung.

Irham,Fahmi. (2013). Analisis Laporan 
Indonesian Journal Of Strategic Management Vol 3, Issue 1, February 2020

DOI: https://doi.org/10.25134/ijsm.v3i1.2815

Keuangan. Alfabeta. Bandung.

Kasmir. (2012). Analisis Laporan Keuangan. Gramedia Persada. Jakarta.

Riyanto,Bambang.(2012). Dasar-dasar Pembelanjaan, Edisi 4. BPFE.
Printed ISSN 2614-5391, e-ISSN 2614-2406 https://journal.uniku.ac.id/index.php/ijsm

Yogyakarta.

Rudianto. (2012). Akuntansi Pengantar. Erlangga. Jakarta.

Sugiyono. (2016). Metode Penelitian Kuantitatif Kualitatif dan R\&D. Alfabeta. 